\title{
Determinants of Beef cattle Market Participation Decision by Smallholder Farmers in Dugda and Bora Districts, Oromia Regional State, Ethiopia
}

\author{
Solomon Ayele ${ }^{1 *} \quad$ Lemma Zemedu ${ }^{2} \quad$ Berhanu Gebremdhin ${ }^{3}$ \\ 1.Socio-Economic Department, Fedis Agricultural Research Center, Oromia Agricultural Research Institute, \\ P.O. box 904, Harar, Ethiopia \\ 2.Department of Agricultural Economics, College of Agriculture and Environmental Science, Haramaya \\ University, P.O. box 138, Dire Dawa, Ethiopia \\ 3.International Livestock Research Institute (ILRI), P.O. box 5689, Addis Ababa, Ethiopia
}

\begin{abstract}
The research is financed by International Livestock Research Institute (ILRI)/Livestock and Irrigation Value chain for Ethiopian Smallholders (LIVES) Project

Abstract

Market participation plays an essential role in generating better income and enhancing welfare of smallholder farmers. This study was aimed to investigate the determinants of smallholder farmers' participation decision in beef cattle market in Dugda and Bora Districts. A multi-stage sampling procedure was used to select sample households for data collection. A total of 152 beef cattle producer sampled households were randomly selected from the districts and semi-structured questionnaires were used to collect data. Both descriptive statistics and probit econometric model were applied to analyze determinants of smallholder farmers' market participation decision in beef cattle market. The findings of the model showed that sex, age, education level of household head, family size, and number of beef cattle owned, crop income and access to market information were significantly affect smallholder farmers' market participation decision in beef cattle market. This study suggested that relevant policy interventions in the directions of above-mentioned aspects are vital to encouraging smallholder farmers' market participation decision in beef cattle market.
\end{abstract}

Keywords: Beef cattle, Market participation decision, Probit Model, Bora and Dugda Districts

DOI: $10.7176 / \mathrm{JNSR} / 9-20-05$

Publication date:October $31^{\text {st }} 2019$

\section{Introduction}

The livestock population of Ethiopia estimates that the country has about 52.1 million heads of cattle, 24.2 million sheep, 22.6 million goats and 44.9 million poultry. About 99.26 percent of the cattle populations are local breeds. Cross-bred and pure exotic cattle account for about 0.64 and 0.1 percent respectively. From these total cattle population estimate about $12.5 \%, 24.73 \%, 0.8 \%, 21.93 \%$ and $3.67 \%$ are used for milk, draught, beef, breeding and other purposes respectively depending on their age category of 3-10 years (CSA, 2015).

Despite the largest number of beef cattle population in the country, farmers lack strategic and market-oriented production system which failed to assist in transforming subsistence farming system into a commercial production system (Ayele et al., 2003). There is a little evidence of strategic production of beef cattle for marketing except some sales targeted to traditional Ethiopian festivals. Sales of beef cattle are taken as a last resort and large ruminants are generally sold when they are old, culled or barren. It is observed that many smallholder farmers (beef cattle herders) do not participated in the beef cattle market. Furthermore, for those households who participate in the market, the size of transaction (sale or purchase of beef cattle) was found to be very small. For example, the number of beef cattle transacted during a year was mostly one (Asfaw and Jabbar, 2008).

Market participation of rural smallholder farmers has been widely seen to be more critical for livelihoods of the rural population as well as its impact on the economic growth of developing countries (Barret, 2008). Hence, analysis of market participation is fundamental to transforming beef cattle production to market orientation then, expected increase market participation. Such an analysis is particularly important in Ethiopia due to large population of beef cattle. However, few research has been conducted in the livestock sector in general and beef cattle sub-sector in particular to investigate market participation and different factors that influence market participation in livestock market in Ethiopia (Mamo and Degnet, 2012; Hailemariam et al., 2009; Negassa and Jabbar, 2008; Gebremedhin et al., 2007). But, no study has been conducted on the determinants of market participation decisions in beef cattle marketing by smallholders in the study areas.

In the study areas beef cattle are one of a few agricultural commodities from which the producers are rely their livelihood and obtain their income to fulfill their needs and economic gaps. Only a small fraction of beef cattle is raised in feedlots. Smallholders are fattening their beef cattle in backyard system. The majority of the producers are uses oxen for draft purpose, and then after finishing draft and become too old they sell for beef purpose. Additionally, barren cows, heifers and bulls are used for beef. But, mostly heifers and bulls are used for 
restocking. Most of the beef cattle produced are used for domestic consumption and very few are supplied to the central market due to low quality (LIVES, 2013). These indicate that there is low market participation by smallholder farmers in livestock in general and particularly beef cattle market in the study areas.

Therefore, this study provides an empirical basis for identifying decisions to increase participation of households in beef cattle market with the objective of investigating determinants of beef cattle market participation by smallholder farmers in Dugda and Bora Districts, Oromia Regional State, Ethiopia.

\section{Research Methodology}

2.1. Description of the study areas

Dugda district: Is composed of 36 rural kebeles and 3 urban kebeles and the district is located about $260 \mathrm{~km}$ south of Addis Ababa and $160 \mathrm{~km}$ east of Adama town. Dry weina-dega and weina-dega which covers about 55\% and $45 \%$, are characterize agro-ecological zones of the district climate respectively. The altitude of the district ranges from 1600 to 2020 meters above sea level. The annual average temperature is $25^{\circ} \mathrm{c}$ whereas the minimum and maximum temperature is $22^{\circ} \mathrm{c}$ and $28^{\circ} \mathrm{c}$ respectively. The district receives average annual rainfall of $750 \mathrm{~mm}$, which is bimodal and erratic in distribution. The main rainy season of the district is from February to mid-May and from July to end of August. The economy of the district is dominated by crop farming mixed with livestock husbandry.

Bora district: Is composed of 18 rural kebeles and the district is located about $238 \mathrm{~km}$ south of Addis Ababa and $138 \mathrm{~km}$ east of Adama town. Dry Weina-Dega covers about 100\% characterize agro-ecological zones of the districts climate. The altitude of the district ranges from 1650 to 2020 meter above sea level. The annual average temperature is $25^{\circ} \mathrm{c}$ whereas the minimum and maximum temperature is $22^{\circ} \mathrm{c}$ and $28^{\circ} \mathrm{c}$ respectively. The district receives annual rainfall of $750-805 \mathrm{~mm}$, which is bimodal and erratic in distribution. The main rainy seasons are from February to mid-May and from July to end of August. The economy of the Woreda is dominated by traditional cash crop farming mixed with livestock husbandry.

\subsection{Sampling Method and Sampling Size Determination}

A multi-stage sampling technique was used to select representative farmer households from the study areas. In the first stage, Dugda and Bora districts were selected purposively based on its potential for beef cattle production and LIVES project intervention districts. In the second stage, with the consultation of district livestock experts and development agents, out of 36 and 18 kebeles from Dugda and Bora districts three and two sample beef cattle producers kebeles namely Abona-Gebrel, Dodota Dambel, Wayo-Gebrel and, Barta-Sami and Malima-Bari kebeles were purposively selected based on their beef cattle production potential and road accessibility to conduct survey respectively. In the third stage, from total list of beef cattle producers in both districts about 152 sample households were randomly selected based on proportional to the population size to selected kebeles. The sample size was determined by using Yemane (1967) simple formula.

$$
\boldsymbol{n}=\frac{N}{1+N\left(e^{2}\right)}
$$

Where, $(\mathrm{n}=$ Sample size $=152, \mathrm{~N}=$ Population size $=5,938$ and $\mathrm{e}=$ Level of precision assumed $8 \%(0.08))$.

\subsection{Types of Data, Data Sources and Methods of Data Collection}

For this study, both qualitative and quantitative data types were used. In order to generate these data both primary and secondary sources were used. The secondary data was also collected from Districts Bureau of Agriculture, Livestock and Fishery Resource Development; Livestock \& Irrigation Value chain for Ethiopian Smallholders Project (LIVES). Primary data was collected from sampled farmer households. Semi- structured questionnaires were used to collect data. Trained and experienced enumerators were participated to collect the data.

\subsection{Methods of Data Analysis}

Both descriptive and econometric analyses were used to analyze the data collected from the beef cattle herders. Descriptive statistics like mean, percentage, frequency, and standard deviation were used to analyze the socioeconomics, demographic and institutional characteristics of beef cattle farmers and probit regression analysis was used to analyses socioeconomic and institutional factors influencing farmers' market participation decision in the beef cattle market in the study areas (Table 1).

2.4.1. Probit Econometric Model specification

$\mathbf{P D i}^{*}=\boldsymbol{\beta X \mathbf { X }}+\mathbf{\varepsilon i}$

$\mathrm{PDi}=1$, if $\mathrm{PDi}^{*}>0$, otherwise $\mathrm{PDi}=0$

Where, PDi* is a latent (unobservable) variable which is the utility of the farmers gets from participating in the beef cattle market; $\mathbf{X i}$ is a vector of independent variables hypothesized to determine households' decision to participate in the beef cattle market; $\boldsymbol{\beta} \mathbf{i}$ is avector of parameters to be estimated; $\boldsymbol{\varepsilon} \mathbf{i}$ is the error term. PDi is discrete response variable for households market participation decision which take a value $\mathbf{1}$ if the households sold beef 
cattle and $\mathbf{0}$ if the households did not sold beef cattle.

\section{Results and Discussion}

\subsection{Socio-economic characteristics of respondents}

Out of total sampled household farmers who engaged in beef cattle keeping, about 66.45 percent of them participated in beef cattle marketing and sold their beef cattle in the existed local market channels while about 33.55 percent of them didn't participated in beef cattle market. The combined households' heads mean age was 42. The mean family size of beef cattle market participants was higher than non-market participants and the tstatistic value showed that significance difference at 5\% significance level. This indicates households with big families will be forced to sell many cattle or participated as seller to meet their households needs (Stroebel, 2004). The mean herd size of beef cattle market participants was higher than non-market participants and the t-statistic value showed that significance difference at 5\% significance level. This revealed that higher herd size increases households' market participation (Vincent et al., 2010; Ehui et al., 2009) (Table 2).

The mean land size of beef cattle market participants was higher than non-market participants and the tstatistic value showed that significance difference at $1 \%$ significance level. This revealed that large land size decreases households' market participation in beef cattle market. Because as land size increases the farmers may use for drafting purposes and keeping large herd size for asset building. Large areas owned by the cattle keepers had negative effect on the household decision to participate in the market as a seller but had a positive effect to participate as the buyer (Asfaw and Jabbar, 2008).

The sex composition of the household heads showed a male dominancy in livestock marketing, with 87.12 percent male and 12.88 percent females which shows that male dominance in beef cattle market (Table 3 ).

\subsection{Results of Probit Econometric Model Analysis}

To determine the factors that influence the probability of smallholder beef cattle producers' participation in beef cattle market in Dugda and Bora districts, probit model was applied. Probit model estimation of the determinants of the probabilities of the households to participate in beef cattle selling was given in (Table 4). Seven variables (age, sex, education, family size, crop income, herd size and access to market information) were significantly found to influence the farmers' decision to participate in the beef cattle market in the study areas.

Age of Household Head (AGHH): As expected, age of household head was negatively associated with farmers' likelihood to sell beef cattle and statistically significant at 5\% significance level. As household head's age increases by a year, the probability that household sell beef cattle decreases by 0.1 percent, holding all other factors constant. This implies that the younger people are more enthusiastic to participate in the beef cattle market than the older people. Barret et al., (2008) stated that younger people participated more in the market because they are more receptive to new ideas and are less risk averse than the older people.

Sex of Household Head (SEXHH): Sex of the household head significantly and positively influenced market participation. Being male-headed household increases the probability of participating in the beef cattle market by $22.6 \%$, all other factors held constant. This suggests that the male headed households were more market oriented than female, hence they participated more in the beef cattle market than female headed households. (Gezehagn, 2015; Sarma et al., 2014) also found male-headed household had significantly and positively influenced market participation in beef cattle market.

Education level of Household Head (EDUHH): As expected, education of household head was positively associated with farmer's likelihood to sell beef cattle and statistically significant at less than $1 \%$ significance level. Marginal effect revealed that as household heads' education level increases the probability that household sell beef cattle increases by $2.9 \%$. This implies that education enhances the skill and ability to better utilize market information, which may reduce marketing costs and make it more profitable to participate in the market (Ehui et al., 2003; Girei and Omonona, 2009; Mohammed et al., 2017).

Family size (FSIZE): Family size was positively associated with farmers' likelihood to sell beef cattle and statistically significant at less than $1 \%$ significance level. Marginal effect revealed that as the family size increases the probability that household sell beef cattle increases by $0.1 \%$. The large household sizes could suggest that the required labor for cattle production and marketing is available in abundance (Musemwa et al., 2007, Mamo and Degnet, 2012).

Crop income (Crop INC): As expected, in this study the annual income earned from farm activities was negatively and significantly influenced the farmers' likelihood to participated in beef cattle market at less than $1 \%$ significance level. As the annual income of the farmers earned from crop production (commercialization) increases by addition of one birr, the probability of the farmers' market participation in beef cattle selling decreases by 14 percent. This result was in line with (Lubungu et al., 2012) which stated that high cop commercialization was negatively and significant impact on the farmers' likelihood to participate in the livestock market in Zambia. Asfaw and Jabbar (2008) also reported that total crop income is negatively associated with household's choice of net seller for cattle and shoats. 
Herd Size (HERDSIZE): Cattle herd-size increases the probability of cattle sales. An increase in herd-size by one unit (TLU) increases the probability of selling cattle by 0.18 percent. The herd size is positively associated with households' choice of net market position for cattle which shows that as the herd size increases the household would be more likely to be a net seller instead of being an autarkic or a net buyer (Asfaw and Jabbar, 2008). Households with large herd size tend to consistently participate in the market. As the herd size reduces the households will move out the market (Lubungu et al., 2012).

Market information (MKTINF): Farmers' access to market information has positively and significantly influenced the probability of farmers' decision to sale beef cattle at less than $1 \%$ significance level. A marginal effect result shows that if farmers get market information, the probability of market participation increases by 70.2 percent. This result similar with the findings (Zamasiya et al., 2014; Sirak and Siegfried, 2007) who reported that access to market information boosts confidence of household who are willing to participate in the market (Table 4).

\section{Conclusion and Recommendations}

Livestock in general and beef cattle in particular play a crucial role in the livelihood of smallholder farmers in the study areas. But, it was observed that smallholder farmers have limited market participation due to various factors. Therefore, this paper examined determinants of Beef cattle Market Participation Decision by Smallholder farmers in Dugda and Bora Districts, Oromia Regional State, Ethiopia. Both descriptive and econometric analyses were used for cross-sectional data gathered from the smallholder beef cattle producers.

The results of probit econometric model showed that social factors (sex of household head, age of household head, education level of household head, and number of family members in the house) were significantly determined famers market participation decision in beef cattle marketing in the study areas. Additionally, economic factors (ownership of herd flock or number of herd size owned and crop income) were significantly determined famers market participation decision in beef cattle marketing in the study areas. Institutional factors (Access to market information) were also important factor that determined farmers' market participation decision. It was concluded that famers' market participation decision in beef cattle marketing in the study areas was determined by socio-economics and institutional factors.

This study recommends that dissemination of relevant market information to smallholder beef cattle farmers is crucial to increase the probability of farmers' market participation decision and as well as receiving fair price for their commodity. Encouraging and supporting the young farmers to be participated in beef cattle marketing is crucial. This may create job opportunities for jobless people through earning income from beef cattle trading at different levels. Increasing production and productivity of beef cattle is another area that needs critical attention. Gender consideration is also important. Up-grading the education level of the household particularly strengthening adults education, and building the capacity of the household that improve their ability is essential.

\section{References}

Asfaw Negassa and Mohammed Jabbar (2008). Commercial Off takes of Cattle under Smallholder Mixed CropLivestock Production System in Ethiopia, its Determinants and Implications for Improving Live Animal Supply for Export Abattoirs. Paper presented at the 4th International Conference on Ethiopian Development Studies. August 2-4, 2007 Western Michigan University Kalamazoo, Michigan, USA.

Ayele S , Assegid W, Belachew H, Jabbar MA,Ahmed MM (2003). Livestock marketing in Ethiopia: A review of structure, performance and development initiatives. Socio-economics and Policy Research Working Paper 52. ILRI (International Livestock Research Institute), Addis Ababa, Ethiopia. 35pp.

Barrett (2008). Smallholder market participation: Concepts and evidence from eastern and Southern Africa. Food Policy 33(4): 299-317.

Central Statistical Agency (2015). Agricultural Sample Survey 2014/15 [2008 E.C]. Volume II report on livestock and livestock characteristics (private peasant holdings)

Ehui, S., Benin, S. and Paulos, Z (2003). Policy options for improving market participation and sales of smallholder livestock producers: A case study of Ethiopia. Paper submitted to the 2nd EAF International Conference on Contemporary Development issues in Ethiopia Addis Ababa, Ethiopia

Ehui, S., Benin, S., and Paulos, A (2009). Policy options for improving market participation and sales of smallholder livestock producers: A case of Ethiopia. http:// academic.research.microsoft.com/publication/5715697. Accessed on 20th March 2010.

Gebremedhin, B., Hoekstra, D., Samson, J., (2007). Heading Towards Commercialization? The Case of Live Animal Marketing in Ethiopia. Improving Productivity and Market Success (IPMS) of Ethiopian Cattle Keepers Project Working Paper 5. ILRI (International Livestock Research Institute), Nairobi, Kenya.

Gezehagn Gesese (2015). Beef cattle value chain analysis in Konso District, Southern People Nation Nationality (SPNN), Ethiopia. M.Sc. Thesis presented the School of Graduate Studies of Haramaya University.

Girei, M.I. and Omonona B.T. (2009). Estimation of determinants of Market participation among cattle farmers in 
Adamawa state, journal of Agricultural Science and Natural Resources. 2 (1): 9-12. Rosefet Academic Publishers

Hailemariam Teklewold, Getachew Legese and Dawit Alemu (2009). Market Structure and Function for Live Animal and Meat Exports in Some Selected Areas of Ethiopia, Research Report 79, EIAR, Addis Ababa Ethiopia.72p.

Livestock and Irrigation Value chain for Ethiopian Small holders (2013). Beef production and marketing: Constraints and opportunities for intervention plan in East shoa zone, unpublished.

Mamo Girma and Degnet Abebaw (2012). Patterns and determinants of livestock farmers' market participation: micro-level evidence. Ethiopian Economics Association, Addis Ababa, Ethiopia.

Mary Lubungu, Antony Chapoto and Gelson Tembo (2012). Smallholder farmers' participation in livestock markets: The case of Zambian farmers: Working paper 66, August, 2012, Indaba Agricultural Policy Research Institute, Lusaka, Zambia.

Mohammed Ibrahim Girei, Josephine Bosede Ayoola, Godwin A. Abu (2017). Socio- Economic Factors influencing the probability of Market Participation among the Cattle Farmers in Adamawa State, Nigeria. International Journal of Environmental and Agriculture Research Vol-3, Issue-11, November, 2017.

Musemwa. L, Chagwiza. C, Sikuka. W, Frase. G, Chimoyo. M and Mzileni (2007). Analysis of Cattle market participation by small scale farmers in the Eastern Cape Province. South Africa. Livestock Research for Rural Development. Volume 19

Sarma, J U Ahmed, A Al-Amin, M Islam and K Fatema (2014). Determinants of market participation in small scale beef cattle Entrepreneurs: evidence from Pabna and Sirajganj districts of Bangladesh.

Sirak.T. Bahta, Siegfried Bauer (2007). Analysis of the determinants of market participation within the South African small-scale livestock sector: Tropentag, October 9-11, 2007, Witzenhausen: "Utilization of diversity in land use systems: Sustainable and organic approaches to meet human needs"

Stroebel A (2004). Socio-economic complexities of smallholder resource-poor ruminant livestock production systems sub-Saharan Africa. Unpublished PhD Thesis. University of the Free State.

Vincent, N., Langat, B., Korir, M. K., Ngeno, K., and Kipsat, M. J (2010). Probability of pastoralists' participation in livestock markets in Eastern Pokot district Kenya. Paper presented at the 12th KARI Biennial Scientific Conference. Www.kari.org. Accessed on 15th March 2010.

Yamane (1967). Statistics: An Introductory Analysis, 2nd Ed.

Zamasiya, B., Mango, N., Nyikahadzoi, K and Siziba, S (2014). Determinants of soybean market participation by smallholder farmers in Zimbabwe. Journal of Development and Agricultural Economics, 6: 49-58.

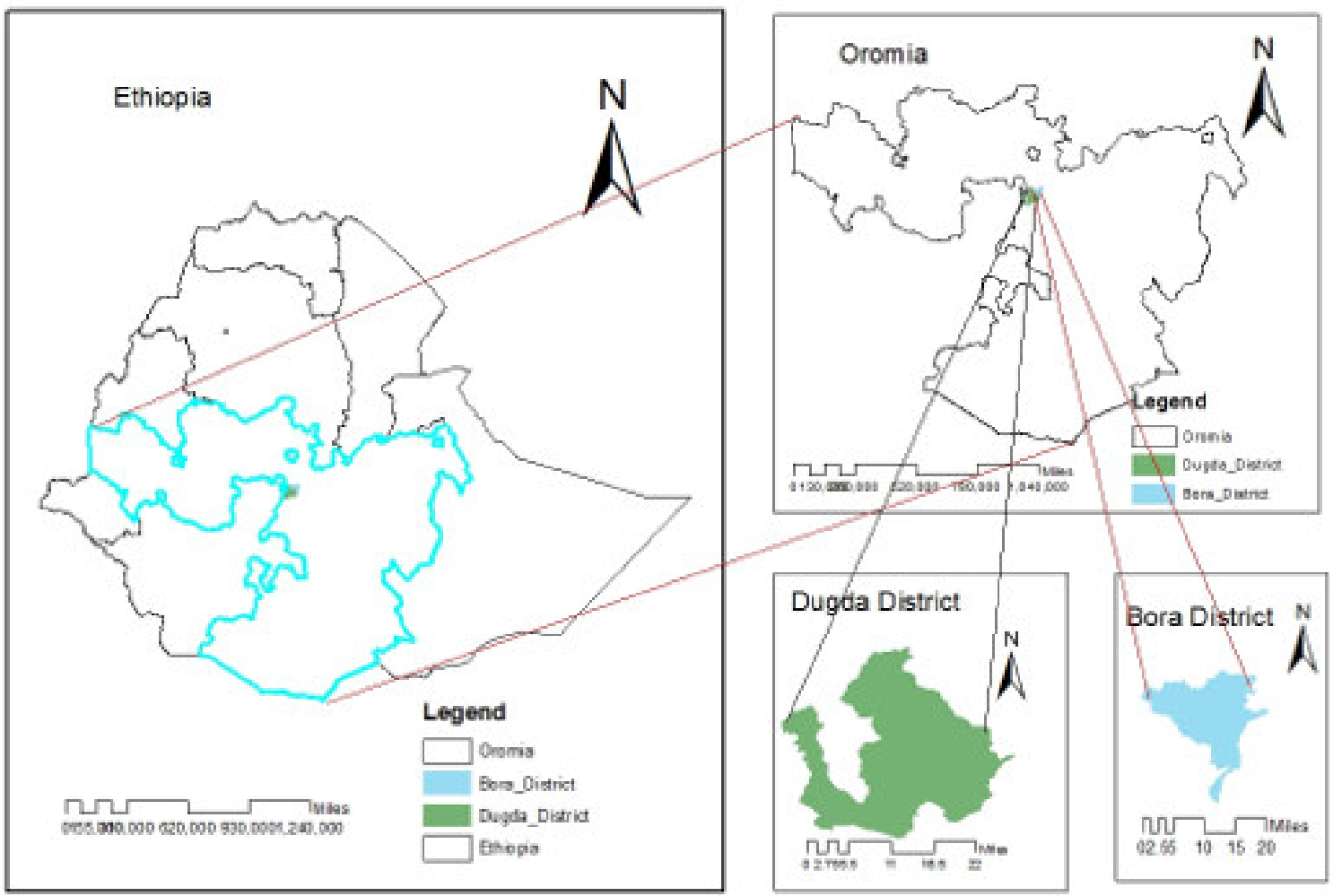

Figure 1. Map Layout of Study Areas - Dugda and Bora District sketched by ArcGIS 10.4 version 
Table 1. Summary of dependent and independent variables used in the probit regression

\begin{tabular}{|c|c|c|}
\hline Variables & Description & $\begin{array}{c}\text { Expected } \\
\text { sign }\end{array}$ \\
\hline Sex of household head & Dummy $(1=$ Male, $0=$ Female $)$ & + \\
\hline Age of household head & Continuous (years) & \pm \\
\hline $\begin{array}{l}\text { Education level of } \\
\text { household head }\end{array}$ & Continuous (years of schooling) & + \\
\hline Family size & Continuous (persons) & + \\
\hline Distance to districts market & Continuous $(\mathrm{Km})$ & \pm \\
\hline Herd size & Continuous (TLU) & + \\
\hline Land holding size & Continuous (hector) & + \\
\hline Access to extension service & Dummy $(1=$ Yes, $0=$ No $)$ & \\
\hline Access to credit service & Dummy $(1=$ Yes, $0=$ No $)$ & + \\
\hline Off-farm income & $\begin{array}{l}\text { Dummy }(1=\text { if household heads involved in off-farm activities, } \\
0=\text { otherwise })\end{array}$ & \pm \\
\hline $\begin{array}{l}\text { Access to } \text { Market } \\
\text { information }\end{array}$ & Dummy $(1=$ Yes, $0=$ No $)$ & + \\
\hline Crop income (1000) & Continuous (Birr) & - \\
\hline
\end{tabular}

Table 2. Mean value of socio-economic and demographic characteristics of beef cattle market participants and non-participants (continuous variables)

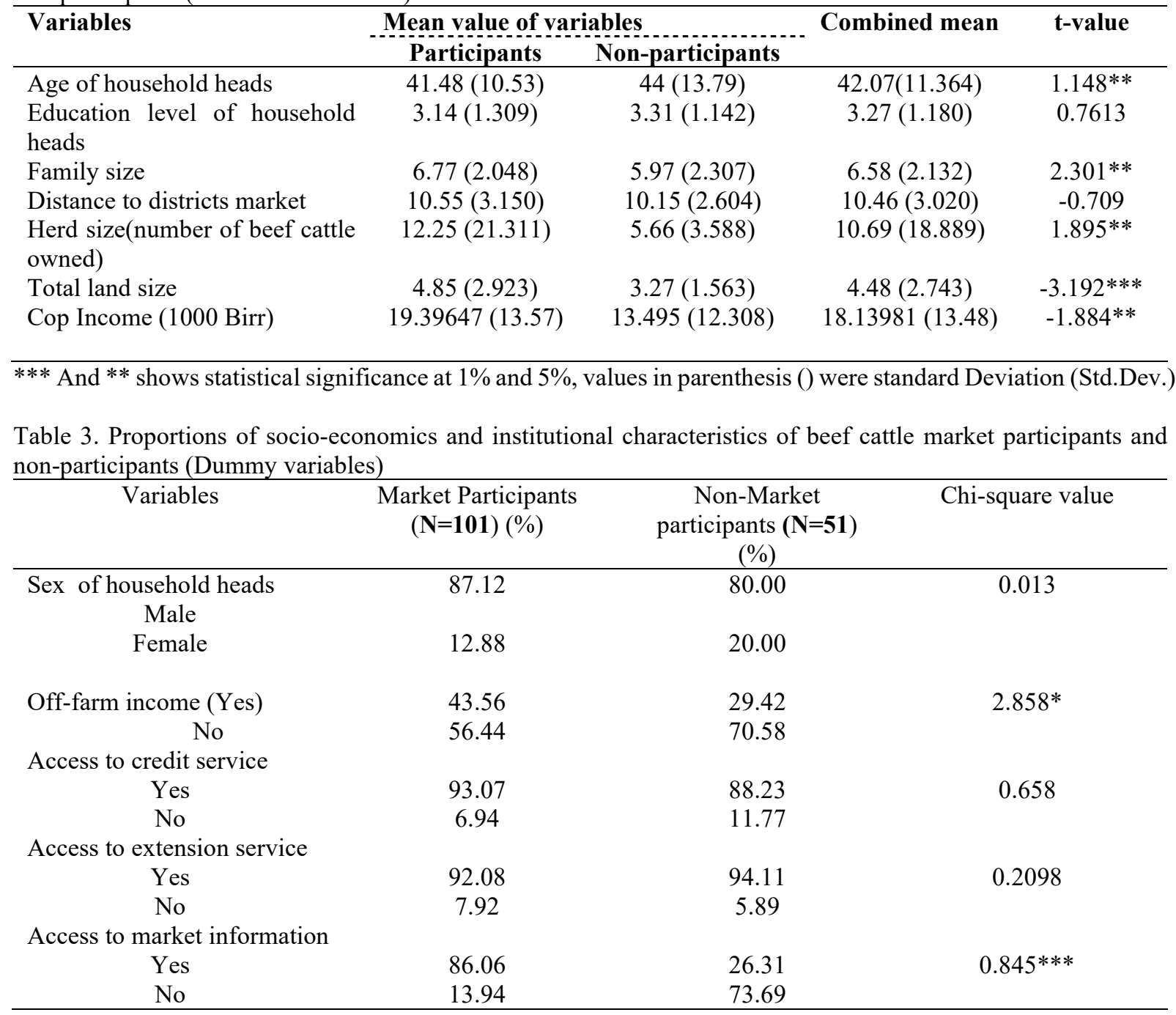


Table 4. Results of marginal effects of probit regression estimation for market participation decision

\begin{tabular}{lcccr}
\hline Variables & Coefficients & Robust SE & Marginal effects (df/dx) & $\mathrm{P}>/ \mathrm{Z} /$ \\
\hline Constant & $-5.84^{* * *}$ & 1.87 & - & 0.002 \\
DMKT & 0.021 & 0.086 & 0.002 & 0.807 \\
SEXHH & $0.0203^{* * *}$ & 0.739 & 0.226 & 0.01 \\
AGHH & $-0.044^{* *}$ & 0.023 & -0.001 & 0.052 \\
EDUHH & $0.466^{* * *}$ & 0.197 & 0.029 & 0.01 \\
FSIZE & $0.424^{* * *}$ & 0.161 & 0.001 & 0.008 \\
LSIZE & 0.263 & 0.235 & 0.018 & 0.269 \\
HERDSIZE & $0.058^{* * *}$ & 0.043 & 0.0018 & 0.000 \\
Crop INC & $-0.0005^{* * *}$ & 0.00001 & $3.66-\mathrm{e} 06$ & 0.011 \\
OFFINC & 0.193 & 0.408 & 0.015 & 0.637 \\
CREDT & 0.837 & 0.604 & 0.077 & 0.118 \\
AEXT & -1.175 & 0.766 & -0.047 & 0.125 \\
MKTINF & $3.145^{* * *}$ & 0.554 & 0.702 & 0.000 \\
\hline SE
\end{tabular}

SE was robust standard error; $* * *, * *$ and $*$ indicate statistical significance level at $1 \%, 5 \%$ and $10 \%$ respectively. Observation $N=152$, Waldchi $^{2}(12)=77.83$, Prob $>$ chi $^{2}=0.0000$, pseudo $R^{2}=0.68$, observed probability $=0.78$, Predicted probability $=0.98$. 